головний науковий співробітник відділу початкової освіти Інституту педагогіки НАПН України,

м. Київ, Україна

ORCID: 0000-0001-5040-0860

e-mail: savchenko.a.j@gmail.com

\title{
ЛІТЕРАТУРНО-ХУДОЖНЯ СПАДЩИНА ВАСИЛЯ СУХОМЛИНСЬКОГО - ДЖЕРЕЛО ЕМОЦІЙНОГО РОЗВИТКУ МОЛОДШИХ ШКОЛЯРІВ
}

Анотація. У статті проаналізовано літературно-художню спадщину Василя Сухомлинського як джерело емоційного розвитку молодших школярів; розглянуто психологічні і педагогічні характеристики емоційного інтелекту, особливості його виявлення й розвитку у молодших школярів.

Схарактеризовано досвід закладів вищої освіти України щодо використання художніх творів Василя Сухомлинського у контексті розвитку емоційного інтелекту майбутніх учителів (Уманського педагогічного університету ім. Павла Тичини, Київського університету ім. Бориса Грінченка, Національного педагогічного університету імені М. П. Драгоманова).

Обгрунтовано потенціал художньої творчості Василя Сухомлинського як джерела розвитку емоційного інтелекту дітей. Розкрито трактування педагогом понять: емоція, емоційність навчання, емоційна культура, школа емоцій. 3'ясовано, що у працях Василя Сухомлинського поняття емоція і думка передбачають тісний взаємозв'язок, який створює емоційний інтелект, що є потужним ресурсом ефективного пізнання дитиною світу природи, людей, праці і самої себе.

Прокоментовано здійснений авторкою відбір творів Василя Сухомлинського для підручників 3 читання у 2-4 класах у контексті завдань розвитку емоційного інтелекту молодших школярів. Обгрунтовано основні критерії вибору творів: їх доступність і цікавість для сучасних дітей, емоційна насиченість, можливість застосування різних форм організації діалогу з текстом, що дозволяє вийти на рівень розуміння внутрішніх смислів твору. Розкрито методичні можливості творів для реалізації таких завдань нової програми 3 мовно-літературної галузі. Схарактеризовано методичні особливості (створення на уроці умов для емоційного сприймання змісту твору учнями i поглиблений аналіз тексту 3 метою проникнення у його внутрішній смисл) та методичні прийоми їх вивчення (прогнозування учнями імовірного змісту твору за його заголовком i малюнком, зіставлення очікуваного i прочитаного твору, «перерване» читання з метою висловлення учнями передбачення на етапі кульмінації сюжету щодо його подальшого розвитку, уявний діалог читачів із дійовими особами твору, придумування продовження подій, звернення до особистого досвіду дітей).

Ключові слова. В. Сухомлинський, літературно-художня спадщина, емоційний інтелект, коло читання, методичні прийоми.

Постановка проблеми. Упродовж останнього десятиліття літературно-художня спадщина Василя Сухомлинського набула виняткової популярності у вчителів, вихователів закладів дошкільної освіти, батьків.

Переконливим щодо цього $є$ ужинок ювілейного року, коли на конференціях, у журналах, в Інтернеті було оприлюднено безліч матеріалів, у яких автори звертались до художніх творів Василя Сухомлинського. Художня спадщина педагога, крім 
підручників, все помітніше входить у коло самостійного вибору дітьми його книг, що засвідчили бібліотекарі Обласних бібліотек для дітей міст Миколаєва, Херсона, Національної бібліотеки України для дітей імені Януша Корчака під час педагогічних читань.

Інтерес до художніх творів Василя Сухомлинського ми пояснюємо тим, що в них розкривається безкінечно різноманітний світ дитячих переживань, думок, мрій, надій, звернених як до юного читача, так і до вдумливого дорослого, який може знайти зерно мудрості і в найпростішому сюжеті. Письменник був майстром коротких оповідань, казок, легенд, притч 3 чітко структурованим, як правило, діалогічним сюжетом та написаних доступною для дітей і водночас образною мовою.

На нашу думку, саме у художній спадщині педагога найбільш виразно відображено його переконання, роздуми, спостереження. Це образне втілення письменником «Педагогіки серця». Тому природним $є$ звернення до художніх творів Василя Сухомлинського на новому етапі розвитку школи як джерела духовного розвитку дитячої особистості. У цьому напрямі ми виокремлюємо аспект, що стосується розвитку у дітей емоційного інтелекту, який набуває зараз особливої актуальності (Козир та Бречко, 2018).

Принципове значення для досягнення у Новій українській школі очікуваних змін $\epsilon$ реалізація нових результатів освіти, які визначені Законом «Про освіту» (2017), Державним стандартом початкової освіти (2018) та передбачені у типовій освітній програмі (2018). До освітніх результатів належать вміння, щзо є спільними для всіх ключових компетентностей. Зокрема: читання з розумінням, уміння висловлювати власну думку усно і письмово; критичне та системне мислення, творчість, ініціативність, здатність логічно обгрунтовувати свою позицію, вміння конструктивно керувати своїми емоціями, оцінювати ризики, приймати рішення, розв'язувати проблеми, співпрацювати з іншими людьми» (Закон України про освіту, 2017, с. 93). 3поміж вищезазначених умінь кілька безпосередньо корелюють із розвитком у дітей емоційного інтелекту.

Аналіз останніх досліджень і публікацій. Феномен емоційного інтелекту останніми роками знайшов різнопланове відображення у психологічних і педагогічних працях. Зокрема, висвітлено функції емоцій, сутність і можливості емоційного інтелекту, особливості його прояву у людей залежно від віку, статі, умов життя тощо.

Звернемось до книги американського дослідника Деніела Гоулмана «Емоційний інтелект». Тут знаходимо відомості про те, що термін емоційний інтелект уперше використали у 1990 роках психологи Джон Маєр та Пітер Саловей. Тепер для його позначення у світі поширена англійська абревіатура E Q або Е I (Гоулман, 2019, с. 78). Деніел Гоулман пише, що лише нещодавно з'явилася в літературі наукова модель емоційного розуму, котра пояснює, як об'єднуються у свідомості людини поняття «емоційність» та «інтелект», як вони взаємодіють у різних видах діяльності. «Емоційний розум реагує набагато швидше, ніж раціональний, - починає діяти, не зволікаючи ані секунди, навіть не зупиняючись, щоб подумати, що він власне робить (Гоулман, 2019., с. 492). Якщо почуття наполегливо нас не відпускають, вони перетворюються на настрій, що $є$ приглушеною формою емоцій. Настрої визначають ефективний тон, але не так активно формують наше сприйняття і поведінку, як емоції в первинному їх вияві» (Гоулман, 2019, с. 495). Емоційний розум може вмить зчитати емоційну реальність ситуації («він сердиться на мене», «вона засмутилася»). «Емоційний розум - це радар для виявлення небезпеки» (Гоулман, 2019, с. 494), - так автор підкреслює особливість прояву емоційного розуму.

У пізнавальному процесі сучасні дослідники визначають такі функції емоцій:

- функція оцінювання (емоції є мовою або системою сигналів, за допомогою яких суб' єкт дізнається про значущість того, що відбувається);

- функція спонукання; 
- дезорганізуюча функція, тобто здатність емоцій порушувати цілеспрямовану діяльність;

- закріплення - гальмування, підкріплення, тобто здатність емоцій залишати сліди в досвіді індивіда;

- функція передбачення, актуалізація слідів, звичайно, випереджає розвиток подій, емоції, що виникають при цьому, сигналізують про можливий приємний або неприємний результат;

- евристична функція (Кондрашова, Федоринова та Міняйленко, 2008, с. 17).

У змістовній монографії М. Шпак «Психологія розвитку емоційного інтелекту молодших школярів» охарактеризовано його сутність і компоненти, відмінності у здатності дівчаток і хлопчиків визначати емоції (Шпак, 2016). Авторка наголошує, що «здатність розуміти власні емоції лежить в основі розуміння емоцій іншого. Водночас розуміння емоцій іншої людини $є$ важливою умовою успішності спілкування та соціальної взаємодії. Особливо це стосується молодших школярів, які зі вступом до школи лише набувають навичок міжособистісної взаємодії безпосередньо в навчальному колективі». (Савченко, 2019, с. 199). На експериментальному матеріалі авторка доводить, що в молодших школярів когнітивний компонент емоційного інтелекту розвинений слабо. Діти краще розпізнають позитивні емоції та вербалізують їх, ніж негативні; визначаючи емоції у спілкуванні, орієнтуються в основному на міміку обличчя. Привертає увагу здійснена на основі експерименту характеристика типів емоційного інтелекту молодших школярів: раціональний, емоційний, соціальноадаптивний, соціально-комунікативний і гармонійний. Встановлено, що найбільшою $є$ група дітей, у яких виявляється соціально-комунікативний тип емоційного інтелекту (Савченко, 2019, с. 249).

Відомо, що у школах деяких зарубіжних країн $є$ спеціальні інтегровані курси для розвитку у дітей емоційного інтелекту (Велика Британія, Іспанія, Мальта, Канада та ін.). Освітяни знають наскільки важливими в японських школах $\epsilon$ уроки милування в природі, створення учнями малюнків, віршів за враженнями від побаченого. Цей досвід $\epsilon$ аналогічним досвіду В. О. Сухомлинського.

3 особливою приємністю відзначаємо зростання інтересу дослідників до використання художніх творів Василя Сухомлинського саме у контексті розвитку емоційного інтелекту студентів у вищій школі. Зокрема, використання художніх творів письменника у підготовці майбутніх учителів. Наприклад, студентами факультету мистецтв Уманського педагогічного університету ім. Павла Тичини здійснено міждисциплінарний проект «Казковий світ Василя Сухомлинського», який було презентовано до 100-річчя педагога (науковий керівник Інна Терешко, декан факультету (Андрощук, Бикова, Грошовик, Киворотенко, Куценко та Терешко, 2018). Засобами хореографічного i образотворчого мистецтва студенти i викладачі представили результати тривалої роботи зі створення хореографічних композицій майбутніми учителями хореографії та музики. У створенні малюнків до творів також брали участь учні Шевченківської спеціалізованої школи-інтернат, що на Черкащині. Важливим додатком до цієї роботи є унаочнення проекту в аудіо-відео супроводі, який підготували майбутні учителі інформатики (Сухомлинський, 2012).

Успішний досвід проектної роботи з інноваційних форм впровадження художніх творів Василя Сухомлинського мають студенти філологічного факультету Університету ім. Бориса Грінченка м. Києва під керівництвом доцента Маргарити Козир (Сухомлинський, 1976, с. 114-117). Масштабний проект із вивчення i популяризації педагогічної і художньої спадщини педагога здійснює творча група дослідників на базі Національного педагогічного університету імені Михайла Драгоманова.

Наш особистий досвід вивчення художньої спадщини Василя Сухомлинського дозволяє стверджувати, що іiі розвивальний потенціал якнайкраще відповідає завданням розвитку емоційного інтелекту молодших школярів. Для його реалізації ми 
здійснили цілеспрямований відбір творів письменника до підручників з читання i запропонували відповідний методичний супровід.

Мета статті - аналіз педагогічної і художньої спадщини Василя Сухомлинського в контексті визначеної проблеми; розкриття потенціалу творів письменника для розвитку емоційного інтелекту учнів початкових класів.

Виклад основного матеріалу. Головним у літературі для дітей Василь Сухомлинський вважав звернення до їхніх почуттів, спонукання до роздумів, які пробуджували або утверджували у вихованців бажання ставати кращими. Можливо, тому педагог придумав такі промовисті назви - «Школа радості», «Школа під голубим небом», «Школа просто неба», які були емоційно надихаючими як для дітей, так і для вчителів.

В аналізі праць педагога нас цікавило, як часто $i$ у якому контексті Василь Олександрович вживав поняття емоції. Виявляється, що досить широко і у різних аспектах. Стосовно окремої дитини він звертався до поняття емоџіï, щоб пояснити, як вона сприймає природу, вчинки, своїх рідних, однолітків, книжку, як вона мислить. Наведу роздуми педагога з книги «Серце віддаю дітям» (розділ «Школа просто неба розсуває стіни», «Наш куточок мрії»). Зверніть увагу, в яких смислах учений вживає це поняття.

«Дитяче бачення світу - це своєрідна художня творчість. Образ, сприйнятий i водночас створений дитиною, несе в собі яскраве емоиійне забарвлення... Емоиійна насиченість сприйняття - це духовний заряд дитячої творчості. Я глибоко переконаний, що без емоційного підйому неможливий нормальний розвиток клітин дитячого мозку. 3 емоційністю пов'язані й фізіологічні процеси, які відбуваються в дитячому мозку: в моменти напруги, піднесення, захопленості відбувається посилене харчування клітин кори півкуль. Клітини в ці періоди витрачають багато енергії, але водночас і багато отримують їі від організму. Ці спостереження по-новому висвітлили процес навчання дітей. Думка учнів початкових класів невіддільна від почуттів $i$ переживань. Емоційна насиченість процесу навчання, особливо сприйняття довколишнього світу - це вимога, яку висувають закони розвитку дитячого мислення» (Сухомлинський, 2012, с. 99-100). Отже, з цих міркувань ми робимо висновок, що не можна перебільшувати роль раціонального і недооцінювати емоційний складник у пізнанні дитиною світу.

«Добрі почуття, емочійна культура, - писав В. Сухомлинський, - це осердя людяності... У дитинстві людина мусить пройти емоційну школу - школу виховання добрих почуттів» (Сухомлинський, 2012, с. 123).

Як бачимо, тут вжито (i y наступних міркуваннях автор продовжує використовувати) кілька базових висловів, які, на мій погляд, мають бути імпульсом для дослідників емоційного інтелекту сучасних дітей: емоційне забарвлення слова, емочійна насиченість сприймання, емочійний підйом, емочійна культура, емочійна школа.

Емоційне виховання дітей $\quad$ В. О. Сухомлинський вбачав у взаємозв'язку із емочійним розвитком вчителя. Він висловлював переконання у тому, що «Без постійного духовного спілкування вчителя і дитини, без взаємного проникнення у світ думок і почуттів, переживань одне одного немислима емоційна культура як плоть $i$ кров культури педагогічної. Найважливіше джерело виховання почуттів педагога - це багатогранні емоційні стосунки з дітьми в єдиному, дружному колективі, де вчитель $\epsilon$ не тільки наставником, а й другом, товаришем» (Сухомлинський, 2012, с. 48).

Молодші школярі емоційно відверті, щирі, їхня душа, мозок відкриті для позитивного впливу. Тому Василь Олександрович наголошував, що виключне значення для малюків має емоційний образ вчителя: зовнішність, голос, жест, погляд, його уміння малювати, співати, розуміти природу, тобто бути цікавою для дітей людиною (Сухомлинський, 1976, с. 507-516). 
Акцентуємо увагу на думках педагога щодо зв'язків між емоціями та інтелектом. «У роки роботи у Павлиській школі, - писав Василь Сухомлинський, - утвердилося ще одне моє педагогічне переконання: процес пізнання навколишньої дійсності $є$ нічим незамінним емоційним стимулом думки... Тонкість почуттів і переживань, чуйна емоційна реакція на глибину, мудрість думки - ці риси духовного світу людини були б абсолютно недосяжні, якби змалечку вона не виховувалася серед природи (Сухомлинський, 2012, с. 54), а також поза впливом музики (Сухомлинський, 2012, с. 125), праці.

Отже, доходимо висновку що у працях Василя Сухомлинського поняття емоиія і думка передбачають тісний взаємозв'язок, який створює емоиійний інтелект, що є потужним ресурсом ефективного пізнання дитиною світу природи, людей, праці і самої себе.

Прокоментуємо здійснений нами відбір творів Василя Сухомлинського для підручників з читання у 2-4 класах у контексті завдань розвитку емоційного інтелекту молодших школярів.

Почуття і мозок сучасної дитини відчувають великий хаотичний потік інформації, що ускладнює їхнє зосередження на суттєвому, розірваність сприйняття, спричинює надмірні збудження емоцій. Для читання і дослідження текстів ми обирали твори 3 чітким сюжетом, який доступний розумінню дітей, може бути для них особистісно значущим або мати слід в емоційному досвіді. У цьому процесі, як і інші педагоги, ми вивчаємо і використовуємо повну збірку казок Василя Олександровича «Я розповім вам казку... Філософія для дітей», яку уклала Ольга Сухомлинська (Сухомлинський, 2016).

Основні критерії вибору творів: їх доступність і цікавість для сучасних дітей, емоційна насиченість, можливість застосування різних форм організації діалогу 3 текстом, що дозволяє вийти на рівень розуміння внутрішніх смислів твору.

Зокрема, ми прагнули розкрити методичні можливості творів для реалізації таких завдань нової програми 3 мовно-літературної галузі: навчити дітей висловлювати своє ставлення до почутого і прочитаного, сприймати художній текст як засіб збагачення особистого емоційно-чуттєвого і соціального досвіду; пояснювати вчинки персонажів твору, висловлювати і обгрунтовувати власні оцінювальні судження (Типові освітні програми для закладів загальної середньої освіти. 1-2 класи, 2018, с. 194-195).

3 огляду на зазначене, для опрацювання на уроках української мови і читання ми пропонуємо для вивчення казки і оповідання, зміст яких допомагає дітям:

розпізнавати емоції персонажів твору;

відчувати свої настрої, почуття в зв'язку з прочитаним і висловлюватись про це;

знаходити у текстах слова, вислови, якими позначено емоції різної спрямованості (пізнавальні, комунікаційні, соціальні);

зрозуміти, що є важливим у стосунках між людьми; що є важливим у ставленні людини до природи, праці;

прогнозувати можливий розв'язок морально-етичної проблеми, яка випливає із змісту твору.

Розпізнавання емоцій та їх правильне означення у слові $є$ для молодших школярів непростим завданням. Це помічав у малюків Василь Олександрович. Він писав, що дитина відчуває значно більше почуттів і відтінків слова, але ії активний словник набагато бідніший.

У змісті підручників і навчальних посібників 3 позакласного читання для 2-4-х класів діти читають майже 50 творів Василя Сухомлинського. Це, з нашого погляду, значний ресурс для навчання дітей у своєрідній «Школі емоцій». Приміром, у новому підручнику для 2 класу діти читають казки «Як Наталя в Лисиці хитринку купила», «Хлопчик і Дзвіночок Конвалії», «Нехай будуть Соловей і Жук», легенду «Вічна тополя», оповідання «Покинуте кошеня», «Глуха дівчинка» та ін. 
Методичними особливостями опрацювання творів Василя Сухомлинського 3 емоціогенним змістом $є$ створення на уроці умов для емоційного сприймання змісту твору учнями і поглиблений аналіз тексту 3 метою проникнення у його внутрішній смисл. Цьому сприяють методичні прийоми: прогнозування учнями імовірного змісту твору за його заголовком і малюнком, зіставлення очікуваного і прочитаного твору, «перерване» читання з метою висловлення учнями передбачення на етапі кульмінації сюжету щодо його подальшого розвитку, уявний діалог читачів із дійовими особами твору, придумування продовження подій, звернення до особистого досвіду дітей (їхні розповіді «А зі мною було так»...).

Висновки i перспективи подальших розвідок. Художні твори Василя Сухомлинського для дітей мають великий потенціал для розвитку емоційного інтелекту, який він вважав обов' язковим чинником успішного навчання. Використання художніх творів письменника передбачає мотивацію дітей до вдумливого читання, проведення уроків-роздумів, обговорення морально-етичних проблем, вибір i обгрунтування учнями своєї позиції щодо вчинків персонажів; сприяє пізнанню світу природи, усвідомленому сприйманню почуттів дійових осіб і власних емоцій.

\section{СПИСОК ВИКОРИСТАНИХ ДЖЕРЕЛ}

Козир, М. та Бречко, А. (2018). Розвиток емоційного інтелекту майбутніх педагогів (на матеріалі творів В. О. Сухомлинського). Наукові записки. Випуск 172; Серія : Педагогічні науки. Кропивницький : «КОД». С. 114-117.

Закон України «Про освіту», (2017) [online]. URL. Режим доступу: http://sakon2.rada.qov.ua/laws/show/2145-19/ [Дата останнього звернення 14.07.2019[

Державний стандарт, (2018): [online]. URL. Режим доступу: http://www.kmu.qov.ua/ua/npas/pro-satverdzhennya-derzhavnoqo-standartu-pochatkovoyiosviti [Дата останнього звернення 14.07.2019[

Типові освітні програми для закладів загальної середньої освіти. 1-2 класи. (2018). Київ: ТД «Освіта-Центр плюс». 240 с.

Гоулман, Д. (2019). Емоційний інтелект. Пер. з англ. С.-Л. Гумецької. Харків : Віват, 2019. 512 с.

Кондрашова, Л., Федоринова, Н. та Міняйленко, А. (2008). Гармонізаиія інтелектуального та емочійного факторів навчання у забезпеченні якісної освіти учнів : Навчально-методичний посібник. Кривий Ріг. 274 с.

Шпак, М. (2016). Психологія розвитку емоційного інтелекту молодиих иколярів. Тернопіль: ТНПУ ім. В. Гнатюка. 372 с.

Савченко, О. (2019). Українська мова та читання. Підручник для 2 класу 33СО (у 2-х частинах): Частина 2. Київ : УОВЦ «Оріон». 144 с.

Андрощук, Л., Бикова, О., Грошовик, І., Киворотенко, А., Куценко, С. та Терешко, I. (2018). Творчий проект "Казковий світ Василя Сухомлинського» у творчості студентів факультету мистецтв (досвід проектної діяльності). Умань : ВПЦ «Візаві». 283 с.

Сухомлинський, В. (2012). Серце віддаю дітям. Харків : АКТА. 537 с.

Сухомлинський, В. (1976). Вибрані твори: в 5 т. [редкол. О. Г. Дзеверін (голова та ін.)]. Київ: Рад. Школа. Т. 2. 670 с.

Сухомлинський, В. (2016). Я розповім вам казку... Філософія для дітей. Харків : ВД «ШКОЛА». $576 \mathrm{c}$.

\section{REFERENCES}

Kozyr, M. \& Brechko, A. (2018). Rozvytok emotsiinoho intelektu maibutnikh pedahohiv (na materiali tvoriv V. O. Sukhomlynskoho) [Development of Emotional Intelligence of Future Teachers (based on V.O.Sukhomlinsky' works]. Naukovi zapysky. Vypusk 172; Seriia : Pedahohichni nauky. Kropyvnytskyi : "KOD”. S. 114-117. (in Ukrainian) 
Zakon Ukrainy pro osvitu [Law of Ukraine "On Education"]. (2017) [online]. URL. Режим доступу: http:/sakon2.rada.qov.ua/laws/show/2145-19/ [Data ostannoho zvernennia 14.07.2019[. (in Ukrainian)

Derzhavnyi standart [State Standard]. (2018) [online]. URL. Режим доступу: http://www.kmu.qov.ua/ua/npas/pro-satverdzhennya-derzhavnoqo-standartu-pochatkovoyiosviti [Data ostannoho zvernennia 14.07.2019]. (in Ukrainian)

Typovi osvitni prohramy dlia zakladiv zahalnoi serednoi osvity. 1-2 klasy. [Typical Educational Programs for General Secondary Educational Institutions. 1-2 grades]. (2018). Kyiv: TD “Osvita-Tsentr plius”. 240 s. (in Ukrainian)

Houlman, D. (2019). Emotsiinyi intelekt [Emotional Intelligence]. Per. z anhl. S.-L. Humetskoi. Kharkiv : Vivat, 2019. 512 s. (in Ukrainian)

Kondrashova, L., Fedorynova, N. ta Miniailenko, A. (2008). Harmonizatsiia intelektualnoho ta emotsiinoho faktoriv navchannia u zabezpechenni yakisnoi osvity uchniv : Navchalno-metodychnyi posibnyk [Harmonization of Intellectual and Emotional Factors of Learning in Providing Quality Education for Students: textbook]. Kryvyi Rih. 274 s. (in Ukrainian)

Shpak, M. (2016). Psykholohiia rozvytku emotsiinoho intelektu molodshykh shkoliariv [Psychology of Developmenta of Emotional Intelligence of Junior Students]. Ternopil: TNPU im. V. Hnatiuka. 372 s. (in Ukrainian)

Savchenko, O. (2019). Ukrainska mova ta chytannia. Pidruchnyk dlia 2 klasu ZZSO (u 2-kh chastynakh): Chastyna 2. [Ukrainian Language and Reading. Textbook for the 2nd Grade of General Secondary School (in 2 parts): Part 2] Kyiv : UOVTs "Orion”. 144 s. (in Ukrainian)

Androshchuk, L., Bykova, O., Hroshovyk, I., Kyvorotenko, A., Kutsenko, S., \& Tereshko, I. (2018). Tvorchyi proekt "Kazkovyi svit Vasylia Sukhomlynskoho" u tvorchosti studentiv fakultetu mystetstv (dosvid proektnoi diialnosti) [Creative Project "The Fairy Tale World of Vasyl Sukhomlynskyi" in the Works of Students at the Faculty of Arts (experience of project activity]. Uman : VPTs "Vizavi". 283 s. (in Ukrainian)

Sukhomlynskyi, V. (2012). Sertse viddaiu ditiam [I Give My Heart to Children]. Kharkiv: AKTA. 537 s. (in Ukrainian)

Sukhomlynskyi, V. (1976). Vybrani tvory: v 5 t. [Selected Works: in 5 vol.] [redkol. O. H. Dzeverin (holova ta in.]. Kyiv: Rad. Shkola. T. 2. 670 s. (in Ukrainian)

Sukhomlynskyi, V. (2016). Ya rozpovim vam kazku... Filosofiia dlia ditei [I'II tell You a Fairy Tale... Philossophy for Children] Kharkiv : VD "ShKOLA". 576 s. (in Ukrainian)

\section{LITERARY AND ART HERITAGE OF VASYL SUKHOMLYNSKYI - SOURCE OF EMOTIONAL DEVELOPMENT OF ELEMENTARY SCHOOLCHILDREN}

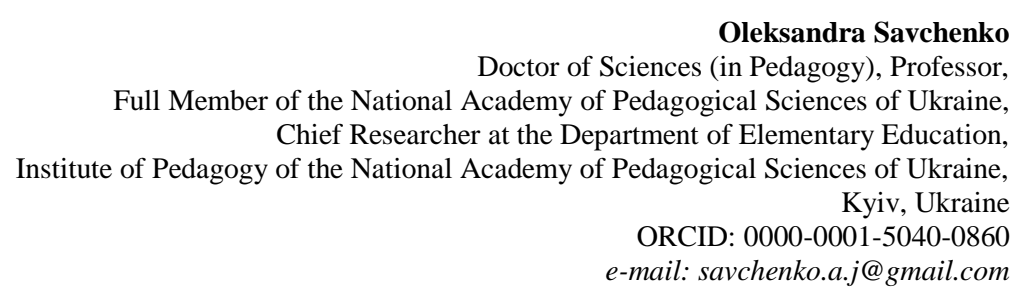

\footnotetext{
Abstract. The article deals with the analysis of the literary and artistic heritage of Vasyl Sukhomlynsky as a source of emotional development of elementary schoolchildren; psychological and pedagogical characteristics of emotional intelligence, peculiarities of its detection and development in elementary schoolchildren are considered.

The experience of institutions of higher education of Ukraine in the use of Vasyl Sukhomlynskyi's literary works in the context of the development of emotional intelligence
} 
of future teachers (Uman Pavlo Tychyna Pedagogical University, Kyiv Borys Hrinchenko University, M. Drahomanov National Pedagogical University) is characterized.

The potential of Vasyl Sukhomlinskyi's literary creativity as a source of development of emotional intelligence of children is substantiated. The teacher's interpretation of the concepts: emotion, emotional learning, emotional culture, school of emotions is revealed. It has been found that in the writings of Vasyl Sukhomlynskyi the concept "emotion" and "thought" imply a close interconnection that creates emotional intelligence, which is a powerful resource for effective knowledge of the child of the world of nature, people, work and herself.

The author made a selection of the works of Vasyl Sukhomlynskyi for reading textbooks in grades 2-4 in the context of the tasks of developing the emotional intelligence of elementary school children. The basic criteria for the selection of works are substantiated: their accessibility and curiosity for modern children, emotional saturation, the possibility of using different forms of organization of dialogue with the text, which allows reach the level of understanding of the internal meanings of the work.

The methodological possibilities of the works for realization of such tasks of the new program in the language and literary field are revealed. Methodical peculiarities (creation of conditions for emotional perception of the content of a work by students and in-depth analysis of the text in order to get into its inner meaning) and methodical methods of their study are characterized (prediction of the student' probable content by its title and drawing, comparison of expected reading) "interrupted" reading with the purpose of students to make predictions at the culmination stage of the plot regarding its further development, imaginary dialogue of readers with the characters of the work, coming up with continuation of events, appealing to the personal experience of children).

Keywords. V. Sukhomlynskyi, literary and artistic heritage, emotional intelligence, reading circle, methodical techniques.

Стаття надійшла до редакиії 18.07.2019 р. 